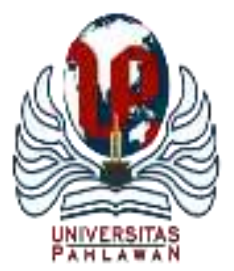

Edukatif : Jurnal Ilmu Pendidikan Volume 3 Nomor 6 Tahun 2021 Halm 4518 - 4531

EDUKATIF: JURNAL ILMU PENDIDIKAN

Research \& Learning in Education

https://edukatif.org/index.php/edukatif/index

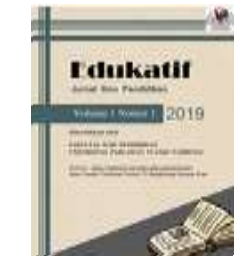

\title{
Kontribusi Permainan Tradisional untuk Hati Nurani Anak
}

\author{
Aurelia Cika Maya Putri ${ }^{1 凶}$, Gregorius Ari Nugrahanta ${ }^{2}$ \\ Universitas Sanata Dharma, Yogyakarta, Indonesia ${ }^{1,2}$ \\ E-mail : aureliacika@gmail.com ${ }^{1}$, gregoriusari@gmail.com²
}

\begin{abstract}
Abstrak
Tujuan dalam penelitian ini melakukan pengembangan buku pedoman permainan tradisional untuk hati nurani pada anak berumur enam tahun sampai delapan tahun. Research and Development $(R \& D)$ jenis ADDIE menjadi tata cara riset yang digunakan. Riset sistematis ini menyertakan tujuh guru dengan beragam daerah guna analisis kebutuhan, delapan orang validator untuk menjadi expert judgement, serta tujuh anak guna pengujian terbatas. Hasil kajian menampilkan jika 1) Buku pedoman mengenai permainan tradisional dibuat berdasarkan tahapan ADDIE, yaitu Analyse, Design, Develop, Implement, serta Evaluate; 2) Buku pedoman permainan tradisional memiliki kualitas dengan kualifikasi "Sangat baik" setara dengan 3,84 (Skala 1-4) dengan saran "Tidak perlu perbaikan"; serta 3) pengaplikasian buku pedoman mempengaruhi karakter hati nurani. Hasil uji signifikansi menampilkan $t(6)=7,439, p=0,000(p<0,05)$. Buku memiliki pengaruh sebesar $r=0,950$ yang berada dalam kualifikasi "Efek besar" ataupun sepadan dengan 90,25\%. Maksudnya, pengaplikasian buku pedoman mengenai permainan tradisional sanggup menunjukkan $90,25 \%$ transformasi varian terjadi pada karakter hati nurani anak. Uji efektivitas didapat dari perhitungan $\mathrm{N}$-gain score sebesar $60,238 \%$ dengan efektivitas "Sedang".
\end{abstract}

Kata Kunci: permainan tradisional, hati nurani, buku pedoman.

\section{Abstract}

This study was to develop a traditional game manual to improve the character of conscience for children aged 6-8 years. This study was conducted with the ADDIE type of research and development $(R \& D)$ method. Seven teachers from various regions for needs analysis, eight validators for expert judgements, and seven children for a preliminary field testing participated in this study. The results showed 1) The traditional game manual was developed according to the stages of ADDIE type, namely Analyse, Design, Develop, Implement, and Evaluate; 2) The quality of the traditional game manual was in the "Very good" category equivalent to a score of 3,84 (Scale 1-4) with the recommendation "No need for revision"; and 3) The application of the manual effected on children's conscience character. The significance test showed $t(6)=7,439, p=0,000(p<0,05)$. The effect size was $r=0,950$ which was included in the "big effect" category or equivalent to 90,25\%. It meant that the implementation could explain 90,25\% of variance changes in conscience characters. The test for the effectiveness of the manual showed $\mathrm{N}$-gain score of $60.238 \%$ equivalent to the "Moderate" category.

Keywords: traditional games, conscience, manual

Copyright (c) 2021 Aurelia Cika Maya Putri, Gregorius Ari Nugrahanta

$\triangle$ Corresponding author

Email : aureliacika@gmail.com

DOI : https://doi.org/10.31004/edukatif.v3i6.1442

ISSN 2656-8063 (Media Cetak)

ISSN 2656-8071 (Media Online) 
4519 Kontribusi Permainan Tradisional untuk Hati Nurani Anak-Aurelia Cika Maya Putri, Gregorius Ari Nugrahanta

DOI: https://doi.org/10.31004/edukatif.v3i6.1442

\section{PENDAHULUAN}

Pendidikan karakter diketahui sebagai gambaran kurikulum yang mendorong anak dalam mengembangkan nilai-nilai dasar dalam dirinya di lingkungan sekolah. Pendidikan karakter ini dapat mengarah pada kemampuan sosial, pembentukan moral, pembiasaan nilai kepedulian, dan berbagai program pengembangan sekolah (Yaumi, 2016). Ketidakseimbangan perkembangan antara aspek kognitif dengan afektif maupun psikomotor akan menyebabkan individu hanya memikirkan sesuatu secara logis tanpa mempertimbangkan moral yang berlaku (Fajri, 2019). Perkembangan teknologi saat ini terjadi sangat pesat. Berdasarkan hasil survei, dalam tiga bulan terakhir tahun 2015, proporsi anak 5 tahun ke atas yang aktif memakai internet di perkotaan meningkat dari $25,84 \%$ menjadi $32,04 \%$, demikian pula di perdesaan, dari 8,37\% menjadi 11,70\% (Sulistyaningtyas \& Fauziah, 2019). Internet, televisi, video game, film, dan iklan semuanya dapat menjadi sumber dampak negatif bagi anak-anak. Semakin banyak fenomena kurangnya karakter hati nurani yang memprihatinkan di lingkungan anak-anak yang disiarkan oleh media-media. Selain itu, hal lain seperi bully juga masih sering terjadi di kalangan anak-anak. Bully dalam tutur kata ataupun perbuatan ialah wujud penghinaan terhadap harkat kemanusiaan. Bullying ialah aksi merendahkan kemanusiaan yang tercermin dalam perilaku serta sikap. Sikap bully sering kali lahir sebab hilangnya empati serta hari nurani (Siboro, 2019). Kasus tersebut berperan dalam perkembangan perilaku anak dan karakter hati nuraninya. Oleh sebab itu, sangat diperlukan pembelajaran yang efektif bagi anak usia 6-8 tahun dengan menekankan pentingnya mengembangkan karakter hati nurani sejak dini sebagai peletakan dasar-dasar pembentukan karakter anak.

Sebagai usaha dalam menumbuhkan karakter hati nurani anak, pemilihan model pembelajaran efektif merupakan yang terpenting. Efektivitas pembinaan karakter dapat tercapai jika saling bersinergi serta kolaboratif dalam mewujudkan pembelajaran yang efektif (Maria et al., 2021). Pembelajaran yang efektif merupakan pembelajaran yang memuat 10 indikator dari pendekatan teoretis berikut. Pendekatan Brain Based Learning diwakili oleh indikator yaitu variety, stimulation, dan menyenangkan. Pendekatan konstruktivisme diwakili oleh indikator operasional konkret. Tuntutan pembelajaran abad 21 diwakili oleh indikator critical thinking, creativity, multicultural, collaboration, serta komunikasi, dan pendidikan karakter diwakili oleh indikator hati nurani. Terdapat banyak kearifan lokal yang bisa diintegrasikan dalam materi pembelajaran guna upaya penguatan, pemahaman, dan karakter bagi anak (Sukarismanti \& Samsudin, 2021). Belajar yang efektif untuk anak-anak dalam kisaran 6-8 tahun pada tahap pengembangan operasional konkret yang dapat dicapai melalui permainan tradisional karena menggunakan benda-benda nyata. Permainan tradisional adalah kegiatan bermain yang berkembang dalam satu generasi di daerah tertentu di mana mengandung nilai-nilai budaya dan memberikan kesenangan bagi para pemainnya. Dengan kegiatan bermain, anak-anak dapat melepaskan kepenatan yang dialami dalam kehidupan sehari-hari mereka. Ketika bermain dengan temanteman, anak memberinya penilaian terhadap dirinya, dia merasa bahwa dia memiliki kompetensi tertentu yang akan membentuk konsep diri, kepercayaan diri, dan harga diri (Nurani et al., 2020). Dalam kegiatan bermain, anak-anak dimungkinkan untuk belajar sendiri melalui kebebasan untuk membayangkan, mengeksplorasi, dan menciptakan sesuatu. Selain itu, permainan tradisional ternyata bisa menjadi titik pijak yang sangat kuat untuk pendidikan karakter karena sangat selaras dengan prinsip-prinsip pembelajaran yang efektif. Penelitian ini mengembangkan buku pedoman dengan permainan tradisional dari lima daerah yang berbeda guna menumbuhkan hati nurani anak berusia 6 tahun sampai dengan 8 tahun.

Melalui studi literatur ditemukan keberhasilan dalam upaya menumbuhkan karakter anak dengan permainan tradisional yang dilakukan penelitian terdahulu. Permainan tradisional adalah warisan pendahulu yang bisa digunakan menjadi rujukan pendidikan karakter yang diajarkan dengan keteladanan serta pembiasaan (Rejeki, 2020). Penelitian lain menyatakan jika permainan tradisional congkak bisa dijadikan media dalam pendidikan karakter (Zafirah et al., 2018). Ditunjukkan juga bahwa pengembangan nilai karakter 
dengan pengembangan model permainan tradisional dikatakan efektif (Widodo \& Lumintuarso, 2017). Kemudian pada penelitian lain disimpulkan bahwa model permainan tradisional efektif dan cocok digunakan dalam membangun karakter siswa sekolah dasar (Kurniawan \& Zawawi, 2017). Permainan tradisional juga dapat menjadi wadah anak dalam mengetahui permainan-permainan di daerah serta tentu saja memberikan pula pengetahuan dan pemahaman atas nilai-nilai yang ada seperti, dapat dipercaya, patuh, sigap, agama, sosial, serta berkolaborasi (Husain \& Walangadi, 2020). Kemudian hasil penelitian lain menampilkan jika permainan tradisional dapat diaplikasikan guna memperkuat karakter tenggang rasa pada subjek PJOK (A'la, 2019). Permainan Bengkak yang berasal dari suku Sasak juga menunjukkan berhasil sebagai media yang dapat membentuk karakter siswa yang disiplin serta jujur (Jiwandono, 2020). Sementara itu, kajian lain menyimpulkan bahwa kearfian lokal yang ada di daerah Sumbawa bisa di integrasikan dengan materi antropolinguistik guna menguatkan pemahaman serta karakter (Sukarismanti \& Samsudin, 2021). Kajian lain mengharapkan kepada para pendidik supaya dapat menyiasati untuk memasukkan unsur kearifan lokal dalam materi yang diampunya sebab metode ini diharapkan dapat mendorong seseorang untuk menjadi individu yang terbuka serta berpikir secara global (Amri, 2021).

Kebaruan penelitian ini dibandingkan dengan penelitian-penelitian terdahulu dapat diringkas dalam tiga unsur, yaitu multidimensi, konsentris, dan gradualitas. Pertama, jika kebanyakan penelitian lebih berfokus pada satu dimensi, metode, atau pendekatan untuk mengembangkan produk, penelitian ini menggunakan pendekatan yang multidimensi, yaitu pendekatan berdasarkan teori pembelajaran berbasis otak (Brain Based Learning), pendekatan konstruktivisme oleh Piaget yakni perkembangan kognitif serta pembelajaran sosial menurut Vygotsky, pendekatan berbasis pembelajaran pada abad 21, dan pendidikan karakter mengenai hati nurani. Kedua, penelitian ini menggunakan model konsentris yang mengembangkan berbagai kegiatan untuk mencapai satu tujuan saja (in finem omnia, semua untuk mencapai satu tujuan) yang terbagi dalam tiga area, yaitu inti (pendidikan karakter hati nurani dengan 10 indikator), pendukung (lima permainan tradisional), dan pengaya (pengembangan permainan tradisional dengan 10 indikator). Ketiga, instrumen pengambilan data mencoba memetakan karakter dalam proses gradual yang tampak dari pilihan jawaban yang tersedia dalam skala 1-4 dimulai dari elemen non-karakter (skor 1), elemen kognitif ( skor 2), elemen afektif (skor 3), dan elemen tindakan (skor 4).

Kajian sistematis ini terbatas guna pengembangan buku tentang permainan tradisional untuk menumbuhkan hati nurani pada anak usia enam hingga delapan tahun. Dalam kajian ini, hati nurani didefinisikan sebagai intuisi yang membantu seseorang dalam berperilaku benar dan dapat membedakan halhal baik dan buruk. Terdapat 10 indikator yang menunjukkan karakter hati nurani, yaitu 1) mengucapkan maaf, 2) memahami kesalahannya, 3) dapat diandalkan, 4) bertindak benar, 5) memahami konsekuensi kesalahannya, 6) memiliki rasa bersalah, 7) malu akan kesalahannya, 8) tidak mudah terpengaruh, 9) mencari kedamaian, dan 10) tahu memperbaiki kesalahannya. Sedangkan, buku pedoman permainan tradisional didefinisikan sebagai buku yang digunakan sebagai petunjuk untuk mengimplementasikan berbagai permainan tradisional dengan 10 indikator pembelajaran yang efektif. Penelitian ini difokuskan untuk merancang sebuah buku pedoman permainan tradisional yang diyakini dapat menjadi upaya dalam menumbuhkan hati nurani anak berumur 6-8 tahun menggunakan 10 indikator, yaitu 1) menyenangkan, 2) operasional konkret, 3) variety, 4) berpikir kritis, 5) stimulation, 6) creativity, 7) multicultural, 8) collaboration, 9) komunikasi, serta 10) hati nurani. Kajian ini bertujuan untuk 1) melakukan pengembangkan buku pedoman permainan tradisional guna meningkatkan karakter hati nurani anak dengan umur 6-8 tahun. Kemudian, 2) mengetahui mutu buku pedoman permainan tradisional terhadap karakter hati nurani anak dengan umur 6-8 tahun. Selanjutnya, 3) mengetahui besarnya pengaruh implementasi buku pedoman permainan tradisional guna mengembangkan karakter hati nurani anak dengan umur 6-8 tahun. 
4521 Kontribusi Permainan Tradisional untuk Hati Nurani Anak-Aurelia Cika Maya Putri, Gregorius Ari Nugrahanta

DOI: https://doi.org/10.31004/edukatif.v3i6.1442

\section{METODE PENELITIAN}

Research and Development $(R \& D)$ jenis ADDIE dipilih sebagai teknik kajian yang diaplikasikan dalam kajian ini. Research and Development ialah desain pengembangan serta validasi suatu produk. Subjek dalam riset ini adalah tujuh anak dengan umur 6-8 tahun guna uji terbatas di Desa Pepe, Muntilan, Magelang, Jawa Tengah. Ada dua objek kajian, yaitu buku pedoman permainan tradisional menjadi variabel bebas sedangkan karakter hati nurani menjadi variabel terikat. Dalam kajian ini, konsep pengembangan produk sejalan dengan tahapan ADDIE, yaitu Analyze, Design, Develop, Implement, serta Evaluate. Berikut digambarkan desain inklusif penelitian $(R \& D)$ jenis ADDIE.

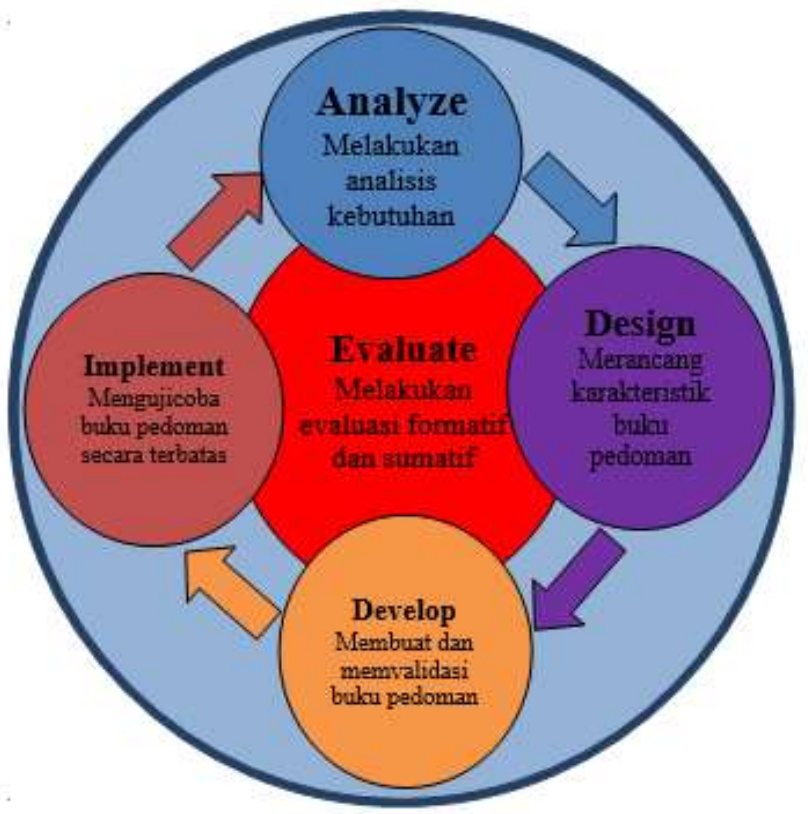

Gambar 1 : Desain Inklusif Penelitian $(R \& D)$ Jenis ADDIE

Berdasarkan gambar di atas, tahap analisis dibuat guna menganalisis kesenjangan atau gap antara cara pembelajaran yang seharusnya dilaksanakan dengan cara pembelajaran yang sebenarnya digunakan dalam upaya menumbuhkan karakter hati nurani anak. Tahap selanjutnya design, secara konkret tahap dilakukan dengan merancang produk guna solusi dari hasil identifikasi masalah. Produk yang dikembangkan merupakan buku pedoman permainan tradisional yang diharapkan bisa menumbuhkan karakter hati nurani anak. Pengembangan buku pedoman dirancang sesuai dengan karakteristik pembelajaran yang efektif sesuai dengan teori yang telah dikaji. Selanjutnya, yaitu tahap develop merupakan pengembangan prototype produk dan validasi kualitas buku pedoman permainan tradisional sebelum dilakukan uji coba produk. Tahap berikutnya, tahap implement merupakan tahap pengujian produk ke dalam pembelajaran. Pengujian produk dilakukan melalui langkah-langkah pembelajaran, seperti kegiatan pembuka, inti, dan penutup. Kemudian tahap evaluate merupakan tahap untuk mengukur kualitas buku. Tahap evaluate ini dilakukan melalui dua bagian penilaian yaitu formatif dan sumatif.

Metode pengumpulan data berupa teknik nontes dan tes yang dipakai guna alat ukur penelitian. Pada tahap analyze teknik nontes yang digunakan adalah kuesioner tertutup dan terbuka untuk anlisis kebutuhan. Kuesioner ditujukan kepada tujuh guru SD di daerah yang berbeda. Pada tahap develop yaitu, kuesioner tertutup untuk validasi permukaan dan isi buku pedoman yang dikembangkan. Validasi produk dilakukan oleh tiga dosen, tiga guru SD, dan dua praktisi. Sedangkan, teknik tes digunakan penilaian formatif dan penilaian sumatif dalam bentuk soal pilihan ganda. Dalam penyusunan pilihan gandanya digunakan skala 1-4 dengan 
gradasi elemen karakter yang mencangkup skor 1 belum menunjukkan adanya komponen karakter, skor 2 menunjukkan unsur pikiran, skor 3 menunjukkan unsur perasaan, dan skor 4 menunjukkan unsur tindakan.

Teknik analisis data penelitian pada tahap analyze dan develop menggunakan skala Likert (1-4). Sedangkan, pada tahap evaluate menggunakan rumus peningkatan dan analisis lebih lanjut. Analisis lebih lanjut terdiri dari pengujian normalitas distribusi data, pengujian signifikansi, dan pengujian besar pengaruh memakai IBM SPSS Statistics 25 for Windows dengan taraf kepercayaan 95\%.

\section{HASIL DAN PEMBAHASAN PENELITIAN}

\section{Hasil Penelitian}

\section{Tahap Analyze}

Tahap analyze dilakukan dengan memberikan kuesioner tertutup dan berbuka untuk analisis kebutuhan kepada total tujuh guru bersertifikat pendidik profesional dengan proporsi lima guru berada di Bekasi, Gunungkidul, Magelang, Karanganyar, Jakarta, dan dua guru dari Kabupaten Sleman di Yogyakarta. Berikut output perhitungan analisis kebutuhan dan patokan perubahan data kuantitatif ke kualitatif (bdk. Widoyoko, 2014).

Tabel 1. Output Perhitungan Analisis Kebutuhan

\begin{tabular}{lll}
\hline No & Indikator & Rerata \\
\hline 1 & Kaya variasi & 1,86 \\
\hline 2 & Kaya stimulasi & 2,14 \\
\hline 3 & Menyenangkan & 1,86 \\
\hline 4 & Operasional-konkret & 1,71 \\
\hline 5 & Berpikir kritis & 1,43 \\
\hline 6 & Kreativitas & 1,50 \\
\hline 7 & Komunikasi & 2,14 \\
\hline 8 & Kolaborasi & 1,86 \\
\hline 9 & Multikultur & 1,57 \\
\hline 10 & Karakter hati nurani & 1,95 \\
\hline & & $\mathbf{1 , 2 0}$ \\
\hline
\end{tabular}

Tabel 2. Patokan Perubahan Data Kuantitatif Ke Kualitatif

\begin{tabular}{lll}
\hline No. & Rentang Skor & Kategori \\
\hline 1. & $3,26-4,00$ & Sangat baik \\
\hline 2. & $2,51-3,25$ & Baik \\
\hline 3. & $1,76-2,50$ & Kurang baik \\
\hline 4. & $1,00-1,75$ & Sangat kurang baik \\
\hline
\end{tabular}

Seperti terlihat dari tabel di atas, indikator berpikir kritis mencapai rerata terendah, yaitu hanya 1,43 . Sementara rerata tertinggi sebesar 2,14 merupakan indikator kaya stimulasi dan indikator komunikasi. Hasil akhir perhitungan analisis kebutuhan menampilkan rerata skor 1,20 yang masuk dalam kualifikasi "Sangat kurang baik". Hal ini dikarenakan upaya menumbuhkan hati nurani anak belum dilaksanakan secara optimal. Sementara itu, hasil analisis kebutuhan dengan kuesioner terbuka juga ditemukan bahwa praktik pembelajaran guna menumbuhkan hati nurani anak tidak dilakukan dengan sistematis dan tidak melalui proses pembelajaran yang dirancang khusus. Media yang ada juga masih sangat terbatas. Belum ada buku untuk mengembangkan hati nurani. Oleh karena itu, analisis kebutuhan menemukan kesenjangan terhadap pembelajaran guna mengembangkan hati nurani yang seharusnya berjalan dengan praktik yang benar-benar terjadi di lapangan. Dengan demikian, ada landasan yang kokoh untuk memberikan solusi bagi penelitian ini dalam bentuk produk yang dikembangkan. 
4523 Kontribusi Permainan Tradisional untuk Hati Nurani Anak - Aurelia Cika Maya Putri, Gregorius Ari Nugrahanta

DOI: https://doi.org/10.31004/edukatif.v3i6.1442

\section{Tahap Design}

Tahap design adalah tahapan selanjutnya setelah mendapati kesenjangan serta merumuskan tujuan yang ingin dicapai dalam penelitian. Tahap ini dilakukan dengan membuat draf buku pedoman permainan tradisional. Blue print buku terdiri dari bagian awal yang terdapat sampul depan, kata pengantar, serta daftar isi. Bagian tengah buku terbagi lagi menjadi 2 bagian. Bagian pertama buku berisikan teori-teori mengenai pembelajaran yang efektif. Bagian kedua buku berisikan contoh pengembangan lima permainan tradisional di Indonesia dari asal daerah yang berbeda. Bagian akhir buku terdapat daftar referensi, lampiran, glosarium, indeks, tentang penulis, dan ringkasan buku. Berikut adalah beberapa bagian buku.
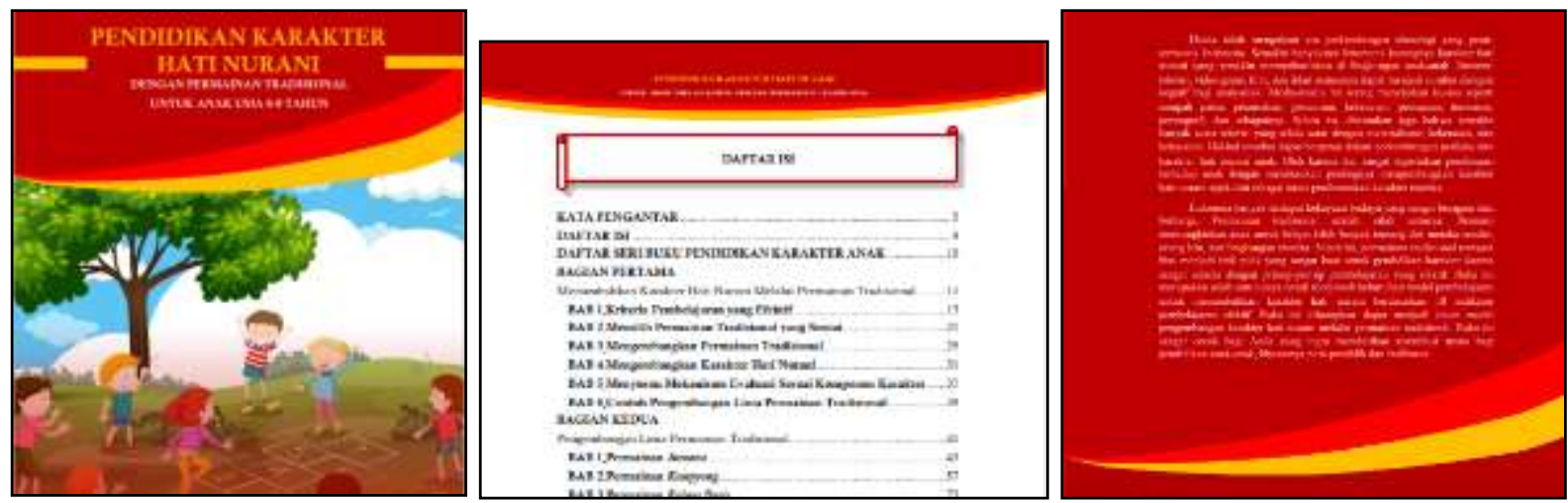

Gambar 2 : Buku Pedoman Permainan Tradisional untuk Hati Nurani Anak

\section{Tahap Develop}

Tahap develop dilakukan validasi terhadap produk melalui expert judgement. Validasi produk ini ditujukan kepada tiga guru sekolah dasar dengan status tersertifikasi sebagai pendidik profesional yang masing-masing ada di daerah Yogyakarta, Muntilan, dan Karanganyar, tiga dosen dengan masing-masing latar belakang keilmuan psikologi anak, media, dan seni, serta dua praktisi atau ahli budaya atau seniman. Adapun keterangan mengenai validator pada uji validitas ini, antara lain validator 1-3 merupakan para dosen, validator 4-5 merupakan para guru SD yang sudah bersertifikat pendidik profesional, dan validator 7-8 merupakan praktisi dalam bidang budaya. Berikut hasil validasi uji permukaan 1 dan patokan perubahan data kuantitatif ke kualitatif dan rekomendasi (bdk. Widoyoko, 2014).

\section{Tabel 3. Hasil Validasi Uji Permukaan 1}

\begin{tabular}{|c|c|c|c|c|c|c|c|c|c|c|}
\hline \multirow{2}{*}{ No } & \multirow{2}{*}{ Indikator } & \multicolumn{8}{|c|}{ Validator } & \multirow{2}{*}{ Rerata } \\
\hline & & 1 & 2 & 3 & 4 & 5 & 6 & 7 & 8 & \\
\hline 1 & Cover buku & 4,00 & 3,75 & 3,50 & 3,75 & 4.00 & 3.75 & 3,75 & 4,00 & 3,81 \\
\hline 2 & Bagian awal buku & 3,67 & 3,33 & 4,00 & 3,67 & 3,33 & 3,67 & 3,67 & 4,00 & 3,67 \\
\hline 3 & Bagian isi buku & 4.00 & 4,00 & 3,67 & 4,00 & 4,00 & 4,00 & 4.00 & 3,67 & 3,92 \\
\hline \multirow[t]{2}{*}{4} & Bagian akhir buku & 4,00 & 4,00 & 4,00 & 4,00 & 4,00 & 4,00 & 4,00 & 4,00 & 4,00 \\
\hline & Rerata & 3,92 & 3,77 & 3.79 & 3,86 & 3,83 & 3,86 & 3,86 & 3,92 & 3,85 \\
\hline
\end{tabular}

Tabel 4. Patokan Perubahan Data Kuantitatif ke Kualitatif dan Rekomendasi

\begin{tabular}{llll}
\hline No. & Rentang Skor & Kategori & Rekomendasi \\
\hline 1. & $3,26-4,00$ & Sangat baik & Tidak perlu revisi \\
\hline 2. & $2,51-3,25$ & Baik & Perlu revisi kecil \\
\hline 3. & $1,76-2,50$ & Cukup & Perlu revisi besar \\
\hline 4. & $1,00-1,75$ & Kurang & Perlu dirombak total \\
\hline
\end{tabular}

Validitas permukaan 1 dalam kajian ini bertujuan guna mengetahui kriteria buku pedoman sudah terpenuhi atau belum. Berdasarkan tabel data hasil validasi uji permukaan 1 di atas rerata skor tertinggi dalam uji permukaan 1 terletak pada indikator bagian akhir buku dengan skor rerata 4,00. Rerata skor terendah 
4524 Kontribusi Permainan Tradisional untuk Hati Nurani Anak - Aurelia Cika Maya Putri, Gregorius Ari Nugrahanta

DOI: https://doi.org/10.31004/edukatif.v3i6.1442

adalah indikator bagian awal buku dengan skor 3,67. Rerata akhir dari keseluruhan hasil validasi uji permukaan 1 didapatkan skor 3,85. Skor tersebut dikonversi (lihat Tabel 4) masuk dalam golongan "Sangat baik" serta masukan "Tidak perlu revisi". Selanjutnya, dilakukan pengujian validitas untuk permukaan 2 yang bertujuan guna mengetahui sudahkah karakteristik buku pedoman terpenuhi. Berikut hasil validasi uji permukaan 2.

Tabel 5. Hasil Validasi Uji Permukaan 2

\begin{tabular}{clccccccccc}
\hline \multirow{2}{*}{ No } & \multirow{2}{*}{ Indikator } & $\mathbf{1}$ & $\mathbf{2}$ & $\mathbf{3}$ & $\mathbf{4}$ & $\mathbf{5}$ & $\mathbf{6}$ & $\mathbf{7}$ & $\mathbf{8}$ & Rerata \\
\cline { 2 - 10 } & \multicolumn{1}{c}{$\begin{array}{l}\text { Self- } \\
\text { instructional }\end{array}$} & 4,00 & 4,00 & 3,00 & 4,00 & 3,83 & 4,00 & 4,00 & 3,67 & $\mathbf{3 , 8 1}$ \\
\hline 2 & Self-contained & 4,00 & 3,00 & 4,00 & 4,00 & 4,00 & 4,00 & 4,00 & 4,00 & $\mathbf{3 , 8 8}$ \\
\hline 3 & Stand-alone & 4,00 & 4,00 & 3,00 & 4,00 & 4,00 & 4,00 & 4,00 & 4,00 & $\mathbf{3 , 8 8}$ \\
\hline 4 & Adaptif & 4,00 & 4,00 & 3,00 & 4,00 & 4,00 & 4,00 & 4,00 & 4,00 & $\mathbf{3 , 8 8}$ \\
\hline 5 & User friendly & 4,00 & 4,00 & 3,00 & 4,00 & 4,00 & 4,00 & 4,00 & 4,00 & $\mathbf{3 , 8 8}$ \\
\hline & Rerata & 4,00 & 3,80 & 3,20 & 4,00 & 3,97 & 4,00 & 4,00 & 3,93 & $\mathbf{3 , 8 7}$ \\
\hline
\end{tabular}

Berdasarkan tabel di atas, rerata skor tertinggi adalah indikator self-contained, stand alone, adaptif, serta user friendly dengan angka 3,88. Rerata terendah ada pada self-instructional dengan skor 3,81. Rerata akhir dari hasil validasi uji permukaan 2 diperoleh skor 3,87. Skor tersebut dikonversi (lihat Tabel 4) masuk dalam golongan "Sangat baik" serta masukan "Tidak perlu revisi". Kemudian, pengujian validitas isi yang bertujuan guna memastikan buku pedoman telah memuat sepuluh indikator pembelajaran yang efektif. Berikut hasil validasi uji isi.

Tabel 6. Hasil Validasi Uji Isi

\begin{tabular}{|c|c|c|c|c|c|c|c|c|c|c|}
\hline \multirow{2}{*}{ No } & \multirow{2}{*}{ Indikator } & \multicolumn{8}{|c|}{ Validator } & \multirow{2}{*}{ Rerata } \\
\hline & & 1 & 2 & 3 & 4 & 5 & 6 & 7 & 8 & \\
\hline 1 & Kaya variasi & 4,00 & 3,00 & 3,00 & 4,00 & 4,00 & 4,00 & 4,00 & 4,00 & 3,75 \\
\hline 2 & Kaya stimulasi & 4,00 & 4,00 & 4,00 & 4,00 & 4,00 & 4,00 & 4,00 & 4,00 & 4,00 \\
\hline 3 & Menyenangkan & 4,00 & 3,00 & 4,00 & 4,00 & 4,00 & 4,00 & 4,00 & 4,00 & 3,88 \\
\hline 4 & $\begin{array}{l}\text { Operasional- } \\
\text { konkret }\end{array}$ & 4,00 & 3,00 & 2,00 & 4,00 & 4,00 & 4,00 & 4,00 & 4,00 & 3,63 \\
\hline 5 & Berpikir kritis & 4,00 & 3,00 & 4,00 & 4,00 & 4,00 & 3,00 & 4,00 & 4,00 & 3,75 \\
\hline 6 & Kreativitas & 4,00 & 3,00 & 3,00 & 4,00 & 3,50 & 4,00 & 4,00 & 4,00 & 3,69 \\
\hline 7 & Komunikasi & 4,00 & 3,00 & 4,00 & 4,00 & 4,00 & 4,00 & 4,00 & 3,00 & 3,75 \\
\hline 8 & Kolaborasi & 4,00 & 4,00 & 4,00 & 4,00 & 4,00 & 4,00 & 4,00 & 4,00 & 4,00 \\
\hline 9 & Multikultur & 4,00 & 4,00 & 3,00 & 4,00 & 4,00 & 4,00 & 4,00 & 3,67 & 3,83 \\
\hline \multirow[t]{2}{*}{10} & $\begin{array}{l}\text { Karakter hati } \\
\text { nurani }\end{array}$ & 4,00 & 3,67 & 3,33 & 4,00 & 4,00 & 4,00 & 4,00 & 3,33 & 3,79 \\
\hline & Rerata & 4,00 & 4,00 & 3,43 & 4,00 & 3,95 & 3,90 & 4,00 & 3,80 & 3,81 \\
\hline
\end{tabular}

Berdasarkan tabel di atas, rerata skor tertinggi dalam uji isi buku pedoman terletak pada indikator kaya stimulasi dan kolaborasi dengan skor 4,00. Rerata paling rendah adalah indikator operasional-konkret dengan angka 3,63. Rerata total validasi uji isi diperoleh skor 3,81. Skor tersebut dikonversi (lihat Tabel 4) termasuk dalam jenis "Sangat baik" dengan masukan "Tidak perlu perbaikan". Secara keseluruhan hasil akhir validasi buku dari expert judgement di atas bisa dirangkum sebagai berikut. 
4525 Kontribusi Permainan Tradisional untuk Hati Nurani Anak - Aurelia Cika Maya Putri, Gregorius Ari Nugrahanta

DOI: https://doi.org/10.31004/edukatif.v3i6.1442

Tabel 7. Hasil Validasi Melalui Expert Judgement

\begin{tabular}{|c|c|c|c|c|}
\hline No & Validasi & Skor & Kualifikasi & Rekomendasi \\
\hline \multirow[t]{3}{*}{1} & Validasi Permukaan & & & \\
\hline & a. Permukaan 1 & 3,85 & Sangat baik & Tidak perlu revisi \\
\hline & b. Permukaan 2 & 3,87 & Sangat baik & Tidak perlu revisi \\
\hline \multirow[t]{2}{*}{2} & Validasi Isi & 3,81 & Sangat baik & Tidak perlu revisi \\
\hline & Rerata & 3,84 & Sangat baik & Tidak perlu revisi \\
\hline
\end{tabular}

Pada tabel di atas, nampak bahwa buku pedoman permainan tradisional guna menumbuhkan hati nurani, memenuhi kriteria dan dirancang sesuai karakteristik buku pedoman. Isi buku pedoman permainan tradisional guna menumbuhkan karakter hati nurani ini juga telah memuat indikator pembelajaran yang efektif. Hal itu ditunjukkan oleh rerata keseluruhan uji validasi diperoleh 3,84. Skor tersebut dikonversikan (lihat Tabel 4) dan ada di jenis "Sangat baik" serta masukan "Tidak perlu ralat".

\section{Tahap Implement}

Tahap implement penelitian ini dilakukan dengan uji coba terbatas yang melibatkan tujuh anak, lima perempuan dan dua laki-laki dengan kisaran umur 6-8 tahun. Uji coba buku permainan tradisional ini diaplikasikan di RW 02, Desa Pepe, Kecamatan Muntilan, Kabupaten Magelang, Provinsi Jawa Tengah. Berdasarkan hasil refleksi dan catatan peneliti, anak-anak nampak antusias dan menikmati prosesnya. Hal ini ditunjukkan dari jawaban dan ekspresi anak-anak. Misalnya, ketika penjelasan aturan permainan anak-anak fokus mendengarkan, anak-anak bermain dengan antusias, dan bertanya lagi setelah kegiatan. Kemudian, hasil kuesioner terbuka yang diberikan kepada empat perwakilan orang tua anak memiliki harapan terhadap kegiatan ini, sebab selain anak-anak dapat lebih mendalam mengenal permainan tradisional yang hampir pudar, orang tua juga setuju bahwa melalui permainan tradisional ini banyak nilai dan pelajaran yang positif.

\section{Tahap Evaluate}

Tahap evaluate bertujuan guna mengetahui seberapa pengaruh pengaplikasian buku permainan tradisional bagi hati nurani anak. Berikut gambar diagram batang peningkatan temuan awal dan akhir.

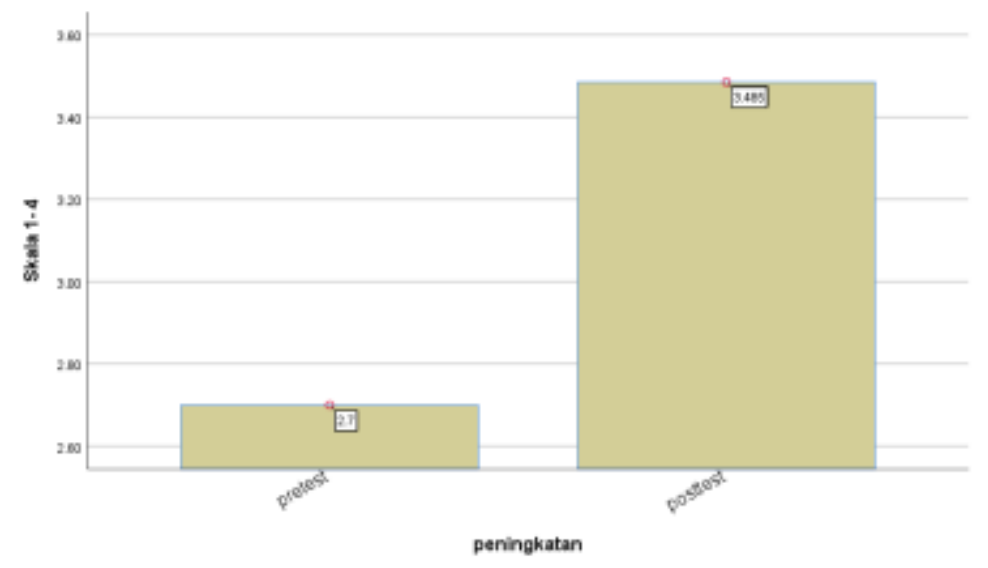

Gambar 3 : Peningkatan Temuan Awal dan Akhir

Dapat dilihat hasil persentase temuan awal dan akhir terjadi peningkatan sebesar 29,07\%. Peningkatan dikatakan signifikan sesudah dilakukan analisis statistik memakai IBM SPSS Statistics 25 for Windows dalam interval keyakinan 95\% untuk dua ekor. Selanjutnya, pengujian normalitas distribusi guna mendapati data yang diteliti penyebarannya normal atau tidak. Berikut adalah tabel output perhitungan normalitas distribusi data. 
4526 Kontribusi Permainan Tradisional untuk Hati Nurani Anak - Aurelia Cika Maya Putri, Gregorius Ari Nugrahanta

DOI: https://doi.org/10.31004/edukatif.v3i6.1442

Tabel 8. Output Perhitungan Normalitas Distribusi Data

\begin{tabular}{ccccc}
\hline Teknik Analisis & Tes & $\boldsymbol{W}$ & $\boldsymbol{p}$ & Keterangan \\
\hline \multirow{2}{*}{ Shapiro-Wilk test } & Pretest & 0,856 & 0,139 & Normal \\
\cline { 2 - 5 } & Posttest & 0,871 & 0,190 & Normal \\
\hline
\end{tabular}

Dari hasil Shapiro-Wilk test menampilkan pretest $W(7)=0,856, p=0,139(p>0,05)$ serta posttest $W(7)$ $=0,871, p=0,190(p>0,05)$. Dengan begitu kedua data normal. Maka, analisis statistik dilanjutkan dengan statistik parametrik, yaitu uji t paired sampel. Berikutnya, pengujian terhadap signifikansi peningkatan pretest ke posttest. Hipotesis statistik $\mathrm{H}_{0}$ dalam kajian ini adalah tidak terdapat selisih yang signifikan. Patokan yang dipakai guna menolak $\mathrm{H}_{0}$ adalah nilai $p<0,05$. Berikut output perhitungan statistiknya.

Tabel 9. Output Perhitungan Signifikansi Peningkatan Pretest ke Posttest

\begin{tabular}{cccc}
\hline Teknik Analisis & $\boldsymbol{t}$ & $\boldsymbol{p}$ & Keterangan \\
\hline Paired samples $t$ test & 7,439 & 0,000 & Signifikan \\
\hline
\end{tabular}

Hasil paired samples $t$ test menampilkan posttest $(M=3,4857, S E=0,09619)$ melebihi pretest $(M=$ $2,7000, S E=0,04364)$ dengan $t(6)=7,439$ dan perbedaan tersebut signifikan $p=0,000(p>0,05)$. Dengan begitu, $\mathrm{H}_{0}$ dibantah, implementasi buku pedoman permainan tradisional memberikan pengaruh pada karakter hati nurani. Selanjutnya, pengujian besaran pengaruh yang dimaksudkan guna mengetahui seberapa pengaruhnya perlakuan dalam hal ini penerapan buku pedoman permainan tradisional. Berdasarkan perhitungan diperoleh $r=0,950$. Selanjutnya, untuk mencari persentase besar pengaruh tersebut, digunakan koefisien determinasi dan diinterpretasikan dengan patokan efek perlakukan sebagai berikut (Cohen, dalam Field, 2009).

Tabel 10. Patokan Efek Perlakukan

\begin{tabular}{ccc}
\hline $\boldsymbol{r}$ (effect size) & Kategori & Persentase (\%) \\
\hline 0,10 & Efek kecil & 1 \\
\hline 0,30 & Efek sedang & 9 \\
\hline 0,50 & Efek besar & 25 \\
\hline
\end{tabular}

Perhitungan dengan koefisien determinasi diperoleh persentase pengaruh sebesar 90,25\%. Sesuai patokan efek perlakuan, koefisien korelasi $r=0,95$ yang termasuk dalam kualifikasi "Efek besar" sebanding dengan pengaruh 90,25\%. Jadi, pengaplikasian buku pedoman dengan permainan tradisional menjelaskan 90,25\% perubahan varian bagi karakter hati nurani anak. Selanjutnya, perhitungan dengan $N$-gain score yang bertujuan guna mengetahui efektivitas dari pengaplikasian buku pedoman dengan permainan tradisional bagi karakter hati nurani anak. Berikut output perhitungan $\mathrm{N}$-gain score dan patokan efektivitas peningkatan.

Tabel 11. Output Perhitungan N-Gain Score

\begin{tabular}{cccccc}
\hline Tes & Rerata & Rentang Skor & SD & N-Gain Score (\%) & Kategori \\
\hline Pretest & 2,70 & \multirow{2}{*}{$1-4$} & 20,19254 & 60,2381 & Sedang \\
\hline posttest & 3,49 & & & & \\
\hline
\end{tabular}


4527 Kontribusi Permainan Tradisional untuk Hati Nurani Anak - Aurelia Cika Maya Putri, Gregorius Ari Nugrahanta

DOI: https://doi.org/10.31004/edukatif.v3i6.1442

Tabel 12. Patokan Efektivitas Peningkatan

\begin{tabular}{ccc}
\hline No. & Rentang Skor (\%) & Kualifikasi \\
\hline 1 & $71-100$ & Tinggi \\
\hline 2 & $31-70$ & Sedang \\
\hline 3 & $0-30$ & Rendah \\
\hline
\end{tabular}

Dapat dilihat pada tabel di atas, hasil $N$-Gain score adalah 60,238\%. Dari tabel patokan efektivitas di atas, nilai tersebut masuk dalam kualifikasi efektivitas "Sedang".

\section{Pembahasan Penelitian}

Kajian sistematis ini sejalan dengan teori karakter yang baik yakni moralitas pada dimensi pengetahuan, perasaan, serta tindakan. Karakter yang baik memuat penalaran yang baik, keinginan untuk hal baik, dan tindakan dengan baik. Ketiganya diperlukan untuk mengarahkan kepada kehidupan bermoral. Saat individu memiliki karakter yang baik maka mereka tahu menilai dengan suatu yang benar, peduli dengan suatu yang benar, kemudian bertindak yang diyakini diri benar, bahkan ketika dihadapkan oleh suatu tekanan (Lickona, 2012). Dalam kajian ini, digunakan analisis semantik untuk menginterpretasikan kata-kata kunci. Analisis semantik adalah analisis guna mendapatkan suatu makna dari sebuah kesatuan bahasa dengan menginterpretasikan keseluruhan teks, analisis semantic biasanya juga dipakai guna menganalisis hubungan makna satu dengan lainnya (Amilia \& Anggraeni, 2019). Dalam penelitian ini, analisis semantik digunakan guna menafsirkan serta mengkategorikan kata kunci berdasarkan makna kajian karakter hati nurani menurut Borba (2008) serta diinterpretasikan juga berdasarkan makna karakter sesuai kajian Lickona (2012). Temuan riset ini menampilkan bahwa pengaruh permainan anak bermakna terhadap pengembangan karakter hati nurani yang masuk dalam tiga dimensi yang dijelaskan. Hasilnya dijelaskan pada diagram berikut.

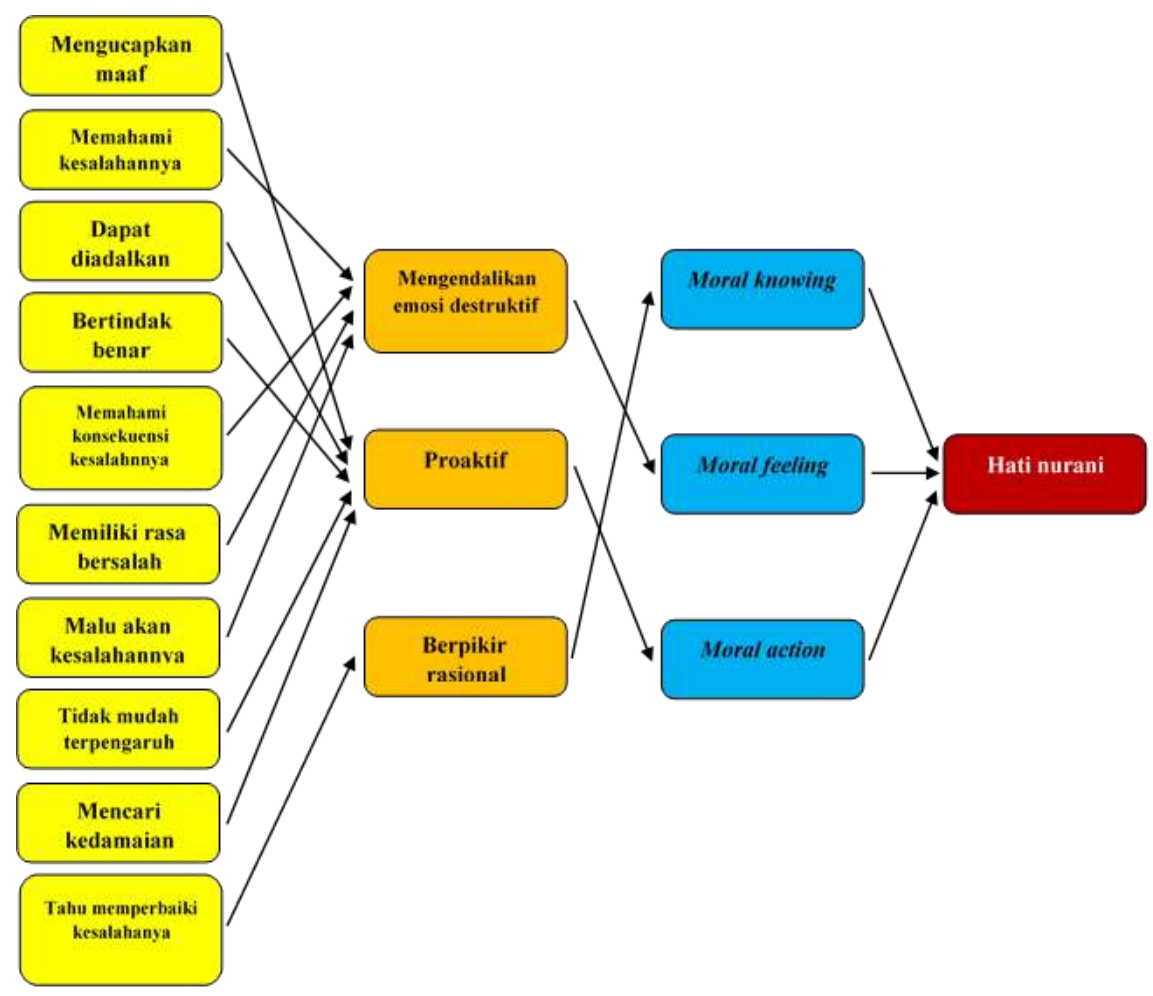

Gambar 4 : Diagram Analisis Semantik Karakter Hati Nurani 
Indikator dari karakter hati nurani diklasifikasikan ke dalam beberapa kata kunci. Indikator memahami kesalahannya, memahami konsekuensi kesalahannya, memiliki rasa bersalah, dan malu akan kesalahannya, mengarah ke subvariabel mengendalikan emosi destruktif. Indikator mengucapkan maaf, dapat diandalkan, bertindak benar, tidak mudah terpengaruh, dan mencari kedamaian, termasuk dalam subvariabel proaktif. Indikator tahu memperbaiki kesalahannya, termasuk dalam subvariabel berpikir rasional. Semua indikator tersebut tertuju kepada karakter hati nurani dengan utuh. Peningkatan indikator-indikator hati nurani tersebut dapat membantu anak guna mengendalikan emosi destruktif, berpikir rasional, dan proaktif. Dengan demikian, karakter hati nurani melibatkan anak dalam pengembangan dirinya secara menyeluruh sebab mencakup ranah cipta, ranah rasa, dan ranah karsanya.

Dalam kajian ini, buku pedoman permainan tradisional dirancang dengan memuat 10 indikator pembelajaran yang efektif, yaitu menyenangkan, operasional konkret, variety, critical thinking, stimulation, creativity, multicultural, collaboration, komunikasi, dan hati nurani. Indikator tersebut dikaji dari teori pembelajaran berbasis otak (Brain Based Learning), basis teori konstruktivisme Piaget dan juga Vygotsky, tantangan pembelajaran abad 21, dan pendidikan karakter hati nurani. Dalam buku ini indikator variety ditampilkan dengan beragam permainan tradisional Indonesia beserta lagu daerahnya dari lima daerah yang berbeda. Kegiatan di dalamnya juga beragam yang terdiri atas kegiatan awal, inti, dan penutup. Indikator stimulation ditampilkan dengan melibatkan seluruh indera seperti untuk bermain, berbicara, melihat, dan mendengarkan. Indikator menyenangkan diperlihatkan melalui reaksi dan ekspresi anak saat bermain seperti sangat antusias dalam permainan. Indikator operasional konkret digunakannya alat bermain dengan benda nyata yaitu diperlukannya alat dan bahan dalam mengdukung permainan. Buku pedoman permainan tradisional ini juga melatih kemampuan kolaborasi anak yakni dengan permainan berkelompok. Dalam indikator kemampuan berpikir kritis ditampilkan saat anak mengerjakan soal formatif dan sumatif dimana anak menganalisis perilaku yang baik dan buruk. Permainan dalam buku pedoman ini juga mendukung kemampuan berpikir kreatif anak saat menjawab pertanyaan refleksi dengan menggambarkan perasaan serta menyampaikan pesan yang didapat setelah melakukan permainan yang memuat karakter hati nurani. Kemahiran komunikasi ditampilkan saat bernyanyi, berpendapat, serta berpendapat dalam kelompok. Kemampuan kolaborasi ditunjukkan saat permainan berkelompok. Dalam inikator ini anak dapat belajar menempatkan dirinya dan ikut serta aktif dalam mencapai tujuan kelompok. Indikator multicultural ditampailakn melalui penggunaan lima permainan tradisional dari berbagai daerah bersama dengan lagu daerahnya. Penelitian ini juga sesuai dengan karakter hati nurani. Hati nurani adalah intuisi seseorang dalam melakukan perilaku yang benar serta membedakan hal baik dan buruk dengan indikator-indikator berikut, yaitu mengucapkan maaf, memahami kesalahannya, dapat diandalkan, bertindak benar, memahami konsekuensi kesalahannya, memiliki rasa bersalah, malu akan kesalahannya, tidak mudah terpengaruh, mencari kedamaian, dan tahu memperbaiki kesalahannya. Hati nurani ditampilkan saat permainan berlangsung, seperti tindakan saling membantu saat orang lain mengalami kesulitan, menunggu giliran bermain dengan sabar, mengikuti peraturan yang telah disepakati bersama, dan jujur atau tidak curang selama bermain.

Penelitian ini sejalan pula dengan penelitian terdahulu namun ada perbedaan dengan kajian oleh beberapa peneliti lainnya. Penerapan permainan tradisional menjadi fasilitas pendidikan karakter di SD (Rejeki, 2020). Menanam nilai karakter kepada siswa melalui permainan congkak sebagai media pembelajaran (Zafirah et al., 2018). Mengembangkan bentuk permainan tradisional guna mendirikan karakter bagi siswa (Widodo \& Lumintuarso, 2017). Permainan tradisional Goteng (Gobak Sodor dan Bentengan) guna membentuk karakter siswa SD di kelas atas (Kurniawan \& Zawawi, 2017). Permainan Awuta, Ponti dan Kainje dalam mengembangkan nilai-nilai karakter pada anak usia dini (Husain \& Walangadi, 2020). Memperkuat toleransi karakter lewat permainan tradisional dalam pembelajaran PJOK (A'la, 2019). Permainan tradisional sebagai cara guna meningkatkan karakter disiplin dan kejujuran (Jiwandono, 2020). 
Menerapkan kearifan lokal saat pengajaran antropilinguistik sebagai usaha untuk memperkuat pemahaman materi dan peningkatan karakter (Sukarismanti \& Samsudin, 2021). Perencanaan pengembangan dan pendidikan berbasis kearifan lokal (Amri, 2021). Penelitian-penelitian tersebut meningkatkan karakter dan menerapkan permainan tradisional dengan menggunakan satu pendekatan saja. Dari penelitian yang sudah ada tersebut, kajian ini jauh lebih sistematis serta komprehensif. Hal tersebut bisa dilihat dari, 1) secara metodologi memakai langkah-langkah $R \& D$ yang lengkap dari analisis kebutuhan sampai dengan uji eksperimental; 2) hasil temuan validasi buku pedoman permainan tradisional menampilkan capaian skor tingga dengan 3,84 (skala 1-4); 3) hasil eksperimental pula menampilkan permainan tradisional memiliki pengaruh besar bagi karakter hati nurani; 4) hasil perhitungan uji efektivitas pengaplikasian buku pedoman menampilkan hasil sebesar 60,238\%; 5) kajian ini sangat komprehensif guna penelitian dalam menumbuhkan karakter hati nurani; dan 6) buku pedoman dengan permainan tradisional ini dikembangkan dari berbagai teori dan juga pendekatan, seperti teori pembelajaran berbasis otak (Brain Based Learning), basis konstruktivisme Piaget serta pembelajaran sosial Vygotsky, pembelajaran berbasis tantangan abad 21, dan pendidikan karakter hati nurani.

Penelitian ini dilakukan sejalan dengan model konsentris yang merupakan pengembangan beberapa kegiatan untuk mencapai satu tujuan, yaitu karakter hati nurani. Model konsentris ini terbagi menjadi tiga area, yaitu inti, pendukung, dan pengaya. Berikut digambarkan analisis dari penelitian ini dengan diagram lingkaran model kosentris.

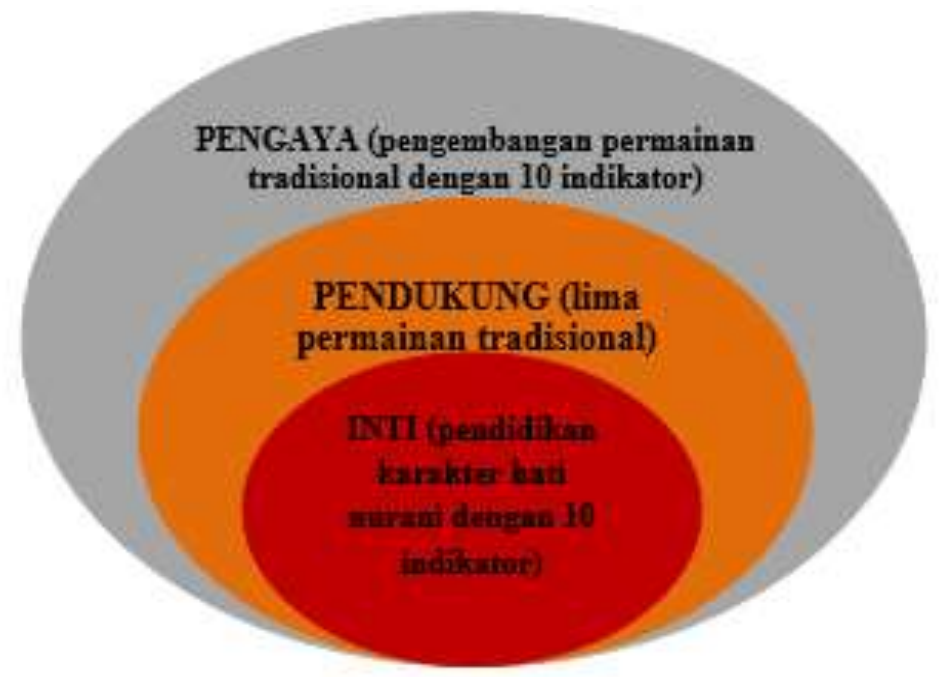

Gambar 5 : Diagram Lingkaran Model Konsentris

Berdasarkan gambar di atas, model konsentris dalam kajian sistemastis ini dibagi dalam tiga area, yaitu inti (pendidikan karakter hati nurani dengan 10 indikator), pendukung (lima permainan tradisional), dan pengaya (pengembangan permainan tradisional dengan 10 indikator). Area inti meliputi pendidikan karakter hati nurani dengan 10 indikator yang merupakan tujuan dari penelitian ini. Sementara itu, area pendukung meliputi lima permainan tradisional, yaitu Kempyeng dari Jawa Timur, Keluar Baris dari Jambi, Tuju Lubang dari Kepulauan Riau, Jumana dari Jawa Tengah, dan Kekuriken dari Nanggroe Aceh Darussalam. Sedangkan area pengaya meliputi pengembangan permainan tradisional dengan 10 indikator pembelajaran yang efektif.

\section{KESIMPULAN}

Berdasarkan dari hasil temuan dan kajian teori yang telah dipaparkan, penelitian ini memperoleh kesimpulan bahwa kontribusi permainan tradisional untuk hati nurani anak dibuat sesuai langkah ADDIE serta didasarkan oleh teori pembelajaran yang efektif. Kualitas buku yang dikembangkan berada di kualifikasi 
4530 Kontribusi Permainan Tradisional untuk Hati Nurani Anak - Aurelia Cika Maya Putri, Gregorius Ari Nugrahanta

DOI: https://doi.org/10.31004/edukatif.v3i6.1442

"Sangat baik". Pengujian validitas mengenai kriteria buku mendapat kualifikasi "Sangat baik". Pengujian validitas untuk karakteristik buku juga berada dalam kualifikasi "Sangat baik". Sementara itu, pengujian validitas isi menampilkan kualifikasi "Sangat baik". Dengan demikian, keseluruhan pengujian validasi produk melalui expert judgement berada di tingkatan "Sangat baik" serta saran "Tidak perlu perbaikan". Pengaplikasian buku pedoman dengan permainan tradisional memiliki pengaruh yang besar bagi hati nurani anak dengan usia 6 tahun sampai dengan 8 tahun. Hasil paired samples $t$ test menampilkan bahwa skor posttest melebihi skor pretest dengan perbedaan yang signifikan. Dengan demikian, $\mathrm{H}_{\text {null }}$ ditolak yang berarti implementasi buku pedoman dengan permainan tradisional memberikan pengaruh terhadap karakter hati nurani. Dengan perhitungan persentase besar pengaruh, buku pedoman berada dalam kualifikasi "Efek besar" atau setara dengan $90,25 \%$ pengaruhnya serta terjadi perubahan varian. Dalam pengujian melalui $N$-Gain score buku pedoman menampilkan skor sebesar 60,238\%, yang berada dalam kualifikasi "Sedang".

\section{DAFTAR PUSTAKA}

A'la, M. (2019). Penguatan Karakter Toleransi Melalui Permainan Tradisional Dalam Pembelajaran PJOK Di Sekolah Dasar. MAGISTRA: Media Pengembangan Ilmu Pendidikan Dasar Dan Keislaman, 10(2), 130. Https://Doi.Org/10.31942/Mgs.V10i2.3108

Amilia, F., \& Anggraeni, A. W. (2019). Semantik Konsep Dan Contoh Analisis. Pustaka Abadi.

Amri, U. (2021). Edukatif: Jurnal Ilmu Pendidikan Perencanaan Pengembangan Dan Pendidikan Berbasis Kearifan Lokal. 3(5), 2025-2031.

Borba, M. (2008). Membangun Kecerdasan Moral: Tujuh Kebajikan Utama Untuk Membentuk Anak Bermoral Tinggi. Gramedia Pustaka Utama.

Fajri, M. (2019). Pengembangan Moral Dan Karakter Di Sekolah Dasar. Guepedia Publisher.

Field, A. (2009). Discovering Statistics Using SPSS ISM (London, England) Introducing Statistical Methods Series.

Husain, R. I., \& Walangadi, H. (2020). Permainan Tradisional Gorontalo Dalam Menumbuhkan Nilai-Nilai Karakter Anak. Jurnal Obsesi: Jurnal Pendidikan Anak Usia Dini, 5(2), 1352-1358. Https://Doi.Org/10.31004/Obsesi.V5i2.839

Jiwandono, I. S. (2020). Permainan Tradisional Sebagai Upaya Peningkatan Karakter Disiplin Dan Jujur Mahasiswa Pendidikan Guru Sekolah Dasar. INVENTA: JURNAL PENDIDIKAN GURU SEKOLAH DASAR, 4 No. 1. Http://Jurnal.Unipasby.Ac.Id/Index.Php/Jurnal_Inventa/Article/View/2137

Kurniawan, W. P., \& Zawawi, M. A. (2017). Pengenalan Permainan Tradisional Goteng ( Gobak Sodor Dan Bentengan ) Untuk Membangun Karakter Pendahuluan Mata Pelajaran Penjasorkes Sangat Penting Diajarkan Pada Sekolah Dasar. Penjasorkes Merupakan Bagian Integral Dari Pendidikan Secara Keseluruhan Ya. 3.

Lickona, T. (2012). Educating For Character: Mendidik Untuk Membentuk Karakter. Bumi Aksara.

Maria, R., Rifma, R., \& Syahril, S. (2021). Efektivitas Pembelajaran Dan Pembinaan Karakter Di Masa Pandemi Covid-19. Edukatif: Jurnal Ilmu Pendidikan, 3(4), 1503-1512.

Nurani, Y., Hartati, S., \& Sihadi. (2020). Memacu Kreativitas Melalui Bermain. Bumi Aksara.

Rejeki, H. (2020). Implementasi Permainan Tradisional Sebagai Salah Satu Sarana Pendidikan Karakter Di Sekolah Dasar. Tadulako Journal Sport Sciences And Physical Education, 8 (1)(96-106), Http://Jurnal.Untad.Ac.Id/Jurnal/Index.Php/PJKR/In.

Siboro, A. F. Y. (2019). Kasus Pembullyan Pelajar Sekolah Dasar Ditinjau Dari Etika Teori Dan Hati Nurani. Https://Doi.Org/10.31227/Osf.Io/62bku 
4531 Kontribusi Permainan Tradisional untuk Hati Nurani Anak - Aurelia Cika Maya Putri, Gregorius Ari Nugrahanta

DOI: https://doi.org/10.31004/edukatif.v3i6.1442

Sukarismanti, \& Samsudin. (2021). Edukatif : Jurnal Ilmu Pendidikan Integrasi Kearifan Lokal Dalam Bahan Ajar Antropolinguistik Sebagai Upaya Penguatan Pemahaman Dan Karakter Mahasiswa. Edukatif: Jurnal Ilmu Pendidikan, 3(5), 3339-3349.

Sulistyaningtyas, R. E., \& Fauziah, P. Y. (2019). Pengembangan Buku Panduan Permainan Tradisional Untuk Meningkatkan Kemampuan Motorik Kasar Anak Usia 5-6 Tahun Developing Traditional Games Handbook To Improve Gross Motor Ability Of 5-6 Years-Old. 6(1), 50-58.

Widodo, P., \& Lumintuarso, R. (2017). Pengembangan Model Permainan Tradisional Untuk Membangun Karakter Pada Siswa SD Kelas Atas. Jurnal Keolahragaan, 5(2), 183 Https://Doi.Org/10.21831/Jk.V5i2.7215

Widoyoko, E. P. (2014). Teknik Penyusunan Instrumen Penelitian. Pustaka Pelajar.

Yaumi, M. (2016). Pendidikan Karakter: Landasan, Pilar \& Implementasi. Prenada Media.

Zafirah, A., Agusti, F. A., Engkizar, Anwar, F., Alvi, F., \& Ernawati. (2018). Penanaman Nilai-Nilai Karakter Terhadap Peserta Didik Melalui Permainan Congkak Sebagai Media Pembelajaran. Jurnal Pendidikan Karakter, 8(1), 95-104. Https://Doi.Org/10.21831/Jpk.V8i1.21678 